\title{
European Integration and Competitiveness of EU New Member States
}

\section{Boris CHISTRUGA}

\author{
Dr. hab, Univ. Prof., Academy of Economic Studies of Moldova
}

Rodica CRUDU

Dr., assoc. prof. Academy of Economic Studies of Moldova

\begin{abstract}
This research is intended to evaluate the influence of the European integration, through the EU financing dimension, upon the evolution of external competitiveness of countries part of the EU community since the enlargements of 2004 and, respectively, 2007, excluding Malta and Cyprus (hereafter called as New Member States (NMS)). The paper methodology is based on appropriate research of relevant economic indicators intended to evaluate the EU funds' influence on the industrial development and external competitiveness of NMS. Therefore, in the analysis performed there were figured out and calculated correlations between the following indicators: EU expenditure by NMS, Current Account to GDP ratio, Industrial Performance index, Global Innovation Index and Index of Economic Freedom. These indicators characterize the NMS' business environment, institutional framework and, consequently, the degree of international competitiveness. The research contributes to confirm the assumptions about the European integration and the EU financing instruments had important effects in improving the industrial performance, in particular, and international competitiveness of NMS, in general. However, the differences in the correlations calculated between EU financing received by the NMS and different analysed indicators, suggest that EU funds were not the only drivers of the increasing competitiveness of the analyzed countries.
\end{abstract}

Keywords: EU financing, Competitiveness, Industrial performance, Innovation.

\section{Introduction}

The European Union is one of the most developed economic regions in the world, registering prosperity levels above the world average. Despite this fact, there are visible socio-economic differences within EU countries, mostly between Western and Eastern EU member countries. Disparities became more evident after EU enlargements waves of 2004 and 2007, when former East European socialist countries, characterized by lower levels of economic progress joined the European community. The new member states (hereafter NMS) have benefited extensively from the European Union's funds, the primary goal of which is to foster the economic development of the region as a whole. European Union has developed and promoted various programs and provided different financing instruments in order to address the existing divergence. The main purpose of EU funds is to support various initiatives and projects to help the new accepted EU members (and not only) to promote convergence, to better integrate countries in the common economic structure and area, to foster economic development and, therefore, the external competitiveness of countries.

The main goal of this research is to identify the influence of EU financing upon the industrial performance and external competitiveness of countries that joined EU in 2004 and 2007, except Malta and Cyprus. The applied methodology relies on the analysis and interpretation of relevant economic indicators intended to evaluate the EU funds' influence on the industrial development and external competitiveness of NMS. For assessing the influence of EU financing on the economic development and, consequently, on external competitiveness of NMS, were analysed and tested several indicators. Most of the indicators (i.e. Ease of Doing Business; Industry, value added (annual \% growth); ICT goods exports (\% of total goods exports); FDI, net inflows (BoP, current US\$) and Global Competitiveness Innovation and Business Sophistication Index), when correlated to the amount of financing received by each NMS did not show any statistical interconnection and 
the analyses performed, were not leading to any relevant conclusions. Therefore, in the analysis performed there were figured out and used the following indicators: EU expenditure by NMS, Current Account to GDP ratio, Industrial Performance index, Global Innovation Index and Index of Economic Freedom. These indicators characterize the NMS' business environment, institutional framework and, consequently, the degree of international competitiveness.

\section{EU funds, industrial development and Competitiveness of NMS: literature review}

The matter researched in this paper is of high concern for EU researchers and economists, it representing a milestone for the future orientation of various European Union's economic policies. Therefore, there is a variety of studies undertaken on this subject. The available literature is not heterogeneous, the vast majority of authors underlining the positive impact of European financing upon the NMS' economic development. They also express the necessity which NMS have had in EU financing to assure functional market mechanisms and effective institutions.

According to Roaf et all (2014) and Balázs P. et all (2014), since the mid 2000's, due to European integration and EU funding, the former socialist countries in Eastern Europe have seen an age of economic growth and macroeconomic stability. Balcerowicz et all (2013) and Rechnitzer (2013) in their papers also noticed the substantial improvement of economic power of Eastern European countries since the integration into the EU, and consequently their increasing external competitiveness. Additionally, a KPMG report highlights the important accomplishments realized by East EU countries, in enhancing their economic potential, tangible transport infrastructure and environmental protection (KPMG, 2014). According to the mentioned report, these areas were neglected during the communist era, but, nowadays, play a huge importance for strong competitiveness of these countries.

Sohinger (2004) explains that the foreign direct investments (FDI) accompanied by the EU financing played a crucial role in assisting the former socialist countries in building a competitive environment for economic development. The same idea is promoted by Sanfey P. and Zeh S. (2012), which mention that the EU integration of NMS improved considerably their economic climate fostering the economic growth and industrial development. It is also mentioned that the most important achievements have been made by East EU countries in areas of innovation, business sophistication, and investment climate leading to a much more favourable ground for industrial growth. In the same context, Hagen T. and Mohl P. (2009) concluded that the allocation of European Union's funds towards NMS, had a positive impact on economic growth of states' regions, including the acceleration of industrial development. However, this improvement did not occur immediately, it requiring several years since the funds have been received and corresponding projects realized (Hagen T. and Mohl P., 2009). Paun (2014) and Becker (2012) in their works, also explain that there is a direct relationship between the absorption rate of EU funds and economic progress of East European countries (Paun, 2014; Becker, 2012). Even if many projects were oriented towards social development and less towards profit earning, the competitiveness in the NMS was enhanced.

Despite the variety of studies in the researched field, a clear identification of the EU funds impact on the competitiveness of NMS is ambiguous. Therefore, the main objective of this research is to identify the correlation between European structural financing and the industrial and overall competitiveness of NMS evolution. Consequently, there is measured the overall performance of countries in attracting EU financing, the efficiency of utilisation and its impact upon the industrial competitiveness. Leaders of economic development in the region and the countries lagging behind are identified. Last, but not the least, the possibilities to enforce the efficiency of financing, in order to obtain the higher returns, are assessed.

\section{The interconnection between EU financing and external competitiveness of NMS}

The NMS became members of the EU in 2004 and 2007, years preceding a long process of negotiations. In order to assure the necessary level of socio-economic compliance, the EU funded a wide range of projects in these countries, focused on institutional and legal empowering. More financing was provided as the countries became members of the community (Table1). The primary goal of EU funding was to accelerate the economic development of NMS, reduce the existing income gap, find solutions for various socio-economic issues characteristic at that time (Balázs P. et all, 2014) and to help member countries to achieve certain objectives in various areas including economic cohesion (Becker, 2012). Five main structural funds work together to support economic development across all EU countries, in line with the objectives of the Europe 2020 strategy: The European Regional Development Fund (ERDF); The European Social Fund (ESF); The Cohesion Fund; European Agricultural Fund for Rural Development (EAFRD); European Maritime and Fisheries Fund (EMFF) and other investment funds (EC, 2014). Based on these funds, the EU poured billions of EUR to stimulate the economic development 
not only in NMS, but of the union as a whole (Roaf et all, 2014). Table 1 provides information regarding the total financing received by EU NMS in the pre and post integration period (Table 1).

NMS benefited extensively from EU funds (Table 1), used to finance various projects oriented to infrastructure development, capacity building and institutional framework, competitiveness stimulation and entrepreneurial development. This fact created favourable conditions for the economic development of NMS and sound drivers for increased external competitiveness. As was mentioned above, in order to assess the influence of EU financing on the economic development and external competitiveness of NMS, were taken into analysis several indicators. Unfortunately, not all of the indicators, when correlated to the amount of financing received by each NMS, showed a statistical interconnection and were not leading to any relevant conclusions. Therefore, it was figured out that the most suitable indicator of showing external competitiveness evolution of NMS is the current account balance to GDP ratio. According to OECD (2016) and World Bank (2016), the ratio of the current account balance to the Gross Domestic Product (or \% of GDP) provides an indication of the country's level of international competitiveness.

Table 1. Total EU funding for New Member States in the period 2000-2014, (EUR million)

\begin{tabular}{|l|l|l|l|l|l|l|l|l|l|l|}
\hline & \multicolumn{4}{|l}{ Baltic Countries } & \multicolumn{4}{l|}{ Central European Countries } & \multicolumn{2}{l|}{ South Eastern EU } \\
\hline & Estonia & Lithuania & Latvia & Poland & Slovakia & Slovenia & $\begin{array}{l}\text { Czech } \\
\text { Republic }\end{array}$ & Hungary & Romania & Bulgaria \\
\hline 2000 & 45 & 48 & 51 & 248 & 62 & 34 & 100 & 156 & 158 & 90 \\
\hline 2001 & 33 & 70 & 57 & 328 & 69 & 56 & 99 & 195 & 248 & 160 \\
\hline 2002 & 43 & 100 & 54 & 532 & 122 & 68 & 254 & 140 & 240 & 143 \\
\hline 2003 & 75 & 307 & 79 & 684 & 104 & 59 & 228 & 190 & 303 & 176 \\
\hline 2004 & 202 & 488 & 267 & 2720 & 388 & 282 & 816 & 713 & 572 & 292 \\
\hline 2005 & 249 & 665 & 385 & 4029 & 609 & 366 & 1075 & 1357 & 634 & 286 \\
\hline 2006 & 300 & 800 & 403 & 5306 & 696 & 406 & 1330 & 1842 & 693 & 361 \\
\hline 2007 & 377 & 1044 & 675 & 7786 & 1083 & 390 & 1721 & 2428 & 1602 & 591 \\
\hline 2008 & 368 & 1134 & 610 & 7639 & 1242 & 456 & 2441 & 2003 & 2666 & 972 \\
\hline 2009 & 716 & 1790 & 710 & 9253 & 1192 & 616 & 2949 & 3569 & 2951 & 979 \\
\hline 2010 & 808 & 1602 & 844 & 11822 & 1905 & 756 & 3416 & 3650 & 2317 & 1222 \\
\hline 2011 & 505 & 1653 & 911 & 14441 & 1785 & 847 & 3029 & 5331 & 2659 & 1107 \\
\hline 2012 & 954 & 1833 & 1179 & 15736 & 2287 & 932 & 4529 & 4177 & 3446 & 1732 \\
\hline 2013 & 973 & 1881 & 1063 & 16179 & 2026 & 814 & 4893 & 5910 & 5561 & 1977 \\
\hline 2014 & 668 & 1886 & 1062 & 17436 & 1669 & 1142 & 4377 & 6620 & 5944 & 2255 \\
\hline TOTAL & 6316 & 15302 & 8351 & 114141 & 15239 & 7224 & 31258 & 38280 & 29995 & 12343 \\
\hline
\end{tabular}

Source: Own processing with the European Commission data, available at: http:// ec.europa.eu/ EU expenditure and revenue 2000-2014 data download (Accessed at 20.07.2016)

As FocusEconomics Consensus Forecasts (2015) explains "The current account is one of the two components of a country's balance of payments, the other being the capital account. It consists of the trade balance (the difference between the total value of exports of goods and services and the total value of imports of goods and services), the net factor income (difference between the return on investments generated by citizens abroad and payments made to foreign investors domestically) and net cash transfers, where all these elements are measured in the domestic currency" (FocusEconomics, 2015). Usually, if the current account to GDP ratio (CA to GDP) is positive and increasing in dynamics, countries are exporting more than importing, meaning a higher general level of external competitiveness. And vice-versa, if a country is importing much more than exporting and have a deficit, this is often a sign that the country is becoming relatively uncompetitive. Therefore, in order to have a general picture over the external competitiveness evolution of EU NMS, the change of the current account to GDP ratio of these countries were recorded and analysed for 2001-2014 period (Figure 1). 
During the pre-crisis years, the countries faced relatively stable current account to GDP ratios, the values slightly decreasing in dynamics. During the deep crisis years 2008-2009, the countries faced a fierce drop in current account to GDP ratio this fact being characterized decreasing exports of NMS (Figure 1). In short, the negative values of current account to GDP ratio are associated with great trade deficits, meaning low levels of exports and high of imports as compared to GDP. Moreover, this indicator describes the huge decrease of inward FDI in these countries during the crisis as compared to precrisis and post crisis years, both meaning less competitive economies in relation with other countries (Balázs $P$. et all, 2014).

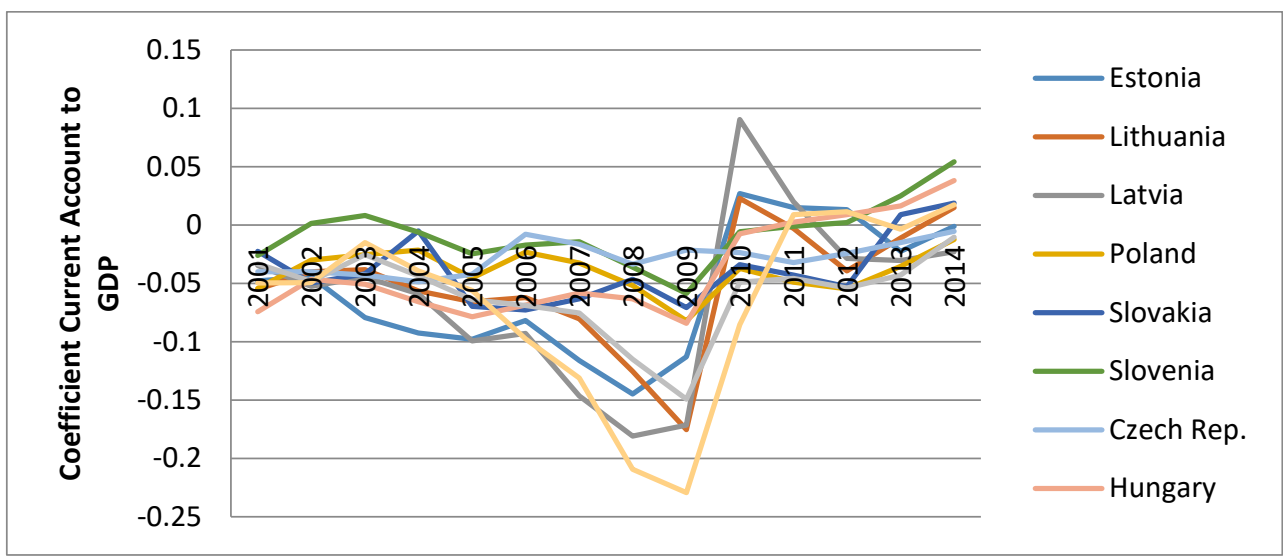

Figure 1. The evolution of Current Account to GDP ratio of EU NMS in the period of 2001-2014, (\%)

Source: Own processing with the World Bank (2016a) data, available at:

http://data.worldbank.org/indicator/BN.CAB.XOKA.GD.ZS (Accessed on: 02.08.2016)

Since 2009, the external competitiveness of NMS has constantly increased (especially in 2010), reaching in a short amount of time values higher that in the pre-crisis period (Figure 1). One of the drivers of external competitiveness of these countries is the received EU funding. It stimulated not only the economic development in the region, but also fostered social and business environment improvement (Balcerowicz et all, 2013). This interconnection is proved by the correlation index between the current account to GDP ratio and the amount of EU expenditure in the region. Consequently, it can be highlighted that the highest positive correlation of these indicators is registered by Hungary $(0,81)$, followed by Czech Republic $(0,66)$, Estonia $(0,50)$ and Slovenia $(0,44)$ (Table 3$)$. Another range of countries are characterized by positive yet sensitively weaker correlation of these indexes and namely: Bulgaria $(0,26)$; Latvia $(0,21)$ and Slovakia $(0,20)$. Finally, countries with almost no correlation between current account to GDP ratio and the amount of EU financing are: Lithuania $(0,13)$; Romania $(0,03)$ and Poland with a slightly negative correlation of $-0,07$. This variance among countries' indicators could be explained by the different economic policies promoted and their success in attracting EU funding. Also, it can be underlined the fact that most of EU funds received by NMS were not oriented towards profit generating facilities, domains which do not directly affect current account to GDP ratio.

Thus, as a general conclusion at this point it is worth to be mentioned that the East European former socialist countries registered lower external competitiveness levels before integration into the European Union, yet still higher than in the crisis years (Rechnitzer, 2013). Integrating deeper into the European Community and recovering from the economic crisis, since 2010 all analysed countries have impressively increased their level of competitiveness. The role of EU financing in enhancing external competitiveness is more visible for some countries and less for the others. Therefore, in order to go deeper into the research issue, other indicators (i.e. Business Innovation Index, Competitive Industrial Performance Index and Index of Economic Freedom) are considered for further analysis. 


\subsection{The influence of EU funding upon the Innovation Performance of NMS}

The national competitiveness can be raised by increasing innovation performance. Innovation enables the countries to adapt to the rapid pace of technological change in order to increase their competitiveness. The analysis of the impact of innovation on competitiveness, confirms that the "innovation paradigm" is sustainable, concerning the recovering competitive advantages lost during the economic crisis (Ciocanela A.B. and Pavelescu A.B., 2015).

Competitive enterprises are the key drivers in a country's competitiveness. They create the core of the economic development. The improving of innovation performance leads to the increasing of national competitiveness. Since their integration into the EU market, the NMS countries have achieved notable results in developing innovative capacities (Roaf et all, 2014). This fact is confirmed by high scores and ranks mentioned in various analyses performed by many research organizations. One of the most reliable assessments is provided by Johnson Cornell University in partnership with INSEAD and World Intellectual Property Organization, which, since 2007, publish the Global Innovation Index. This index ranks countries according to innovation performance, which takes into consideration the countries' inputs such as: R\&D spending, governmental policies, industrial infrastructure, technological sophistication, human capacity and business markets (capital) and outputs: knowledge, competitiveness and wealth (WIPO, 2015).

Innovation is one of the most important priorities of the European Union development strategy. Consequently, most of expenditure is oriented to either directly financing R\&D or stimulating the demand for innovation and high tech products. The EU NMS are not an exception from this general EU objective, the majority of projects funded by EU are oriented towards fostering the technology transfer and innovation development in the region. Figure 2 represents the evolution of countries' innovation performances according to the Global Innovation Index (Figure 2). The analysis of data provided by the Global Innovation Index (GII) represented in the Figure 2 highlights the fact that all EU NM countries increased their innovation competitiveness ranks. This shows that almost all NMS increased their innovative capacities, which is one of the most powerful drivers of economic development. The calculation performed, prove that in most of the NMS there is a strong positive correlation between the amounts of financing received by each country and GII. Thus, the highest correlation is registered by Latvia $(0,96)$, Poland and Lithuania $(0,85)$, followed by Slovenia $(0,82)$, Bulgaria $(0,76)$, Czech Republic $(0,75)$. Positive, but still moderate correlation of these indicators is also registered by Hungary $(0,65)$, Estonia $(0,58)$ and Romania $(0,42)$. The only exception is Slovakia, the correlation indicator of which is negative $(-0,82)$ (Table 3$)$.

This fact means that for all NMS, except Slovakia, the growth of EU financing had a beneficial impact upon the improvement of innovative capacities. These findings are in the same trend with the findings of. Ciocanela A.B and Pavelescu FI. M. (2015), that figured out that "the improving with $+5 \%$ of innovation performance, according to Innovation Union Scoreboard, leads to the increase of the national competitiveness with +2.32 points, calculated in accordance with IMD World Competitiveness Yearbook, and if the innovation performance will increase with $+10 \%$ the national competitiveness will increase with +4.63 points" ( A.B. Ciocanela and FI. M. Pavelescu, 2015)

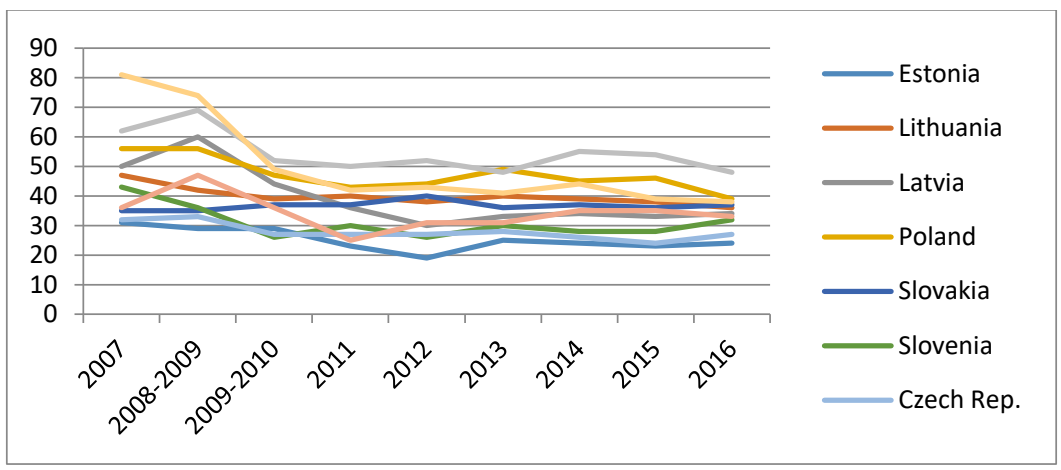

Figure 2. Evolution of Global Innovation Index rank of NMS, 2007-2016

Source: Own processing with the Global Innovation Index, available at: https://www.globalinnovationindex.org/analysisindicator. (Accessed on 25.07.2016) 
The correlation between EU funds and Innovation performance of the analysed countries highlights that EU expenditure in the region favoured the innovation due to the interconnectivity with all areas of economic activity, starting with research and development (R\&D) and finishing with distribution and retailing. Some sectors are characterized by rapid change and radical innovations, others by smaller, incremental changes. In high-tech sectors, R\&D plays a central role in innovation, whereas other sectors rely to a greater degree on the adoption of existing knowledge and technology. Low- and medium-tech industries are often characterized by incremental innovation and by the adoption of foreign technology. New technologies based on broad areas of scientific research-such as energy, material and biological sciences and information technologies-that are rapidly diffused are examples of technological breakthroughs. Such new technologies are probably fuelling the next wave of global economic growth. A dozen new economically disrupting technologies that might have a huge effect in years to come include mobile Internet, cloud technology, advanced robotics, autonomous vehicles, energy storage, 3-D printing, advanced materials and renewable energy (Manyika et all, 2013). These technologies have the potential to affect billions of consumers, hundreds of millions of workers and trillions of dollars of economic activity across different industries. In the long run, the ability of a country to use existing and to innovate new technology determines its economic performance through a process of structural change. Nevertheless, the analysis of correlation of EU funds with Competitive Industrial Performance Index highlights a little bit different picture.

\subsection{The correlation analysis between NMS' Competitive Industrial Performance Index and EU funding}

According to the UNIDO (United Nations Industrial Development Organization) the Competitive Industrial Performance (CIP) measures the capacity of countries to increase their presence in international and domestic markets, whilst developing industrial sectors and activities with higher value added and technological content. As a performance indicator, CIP reflects a country's productivity, structural change and competitiveness. These concepts are taken as a departure point for the selection of indicators under the three major dimensions. The first dimension includes manufacturing value added (MVA) per capita, which is the ratio of output to the country's population. This indicator represents the level of overall productivity and 4 quantifies the country's capacity to produce. Another indicator of the same dimension shows the extent of the realization of domestic manufacturing products in external markets. The second dimension of the CIP consists of indicators relating to the intensity of industrialization and the quality of manufactures exports. As industrialization progresses, two forms of major structural change may occur. First, the manufacturing sector's position in the overall economy may strengthen (increased share of MVA in GDP) and second, a gradual shift from low-technology and resource-based to hightechnology products may occur. Increasing levels of industrialization trigger the export of high-technology and high quality products. The third dimension comprises indicators on the country's share in the world market and thus introduces exogenous factors into the analytical framework of the CIP (UNIDO, 2015).

The analysis of the evolution of CIP values of the selected countries in the period of $2001-2012$, underline the positive trend for all NMS in fostering their industrial competitiveness (Figure 3).

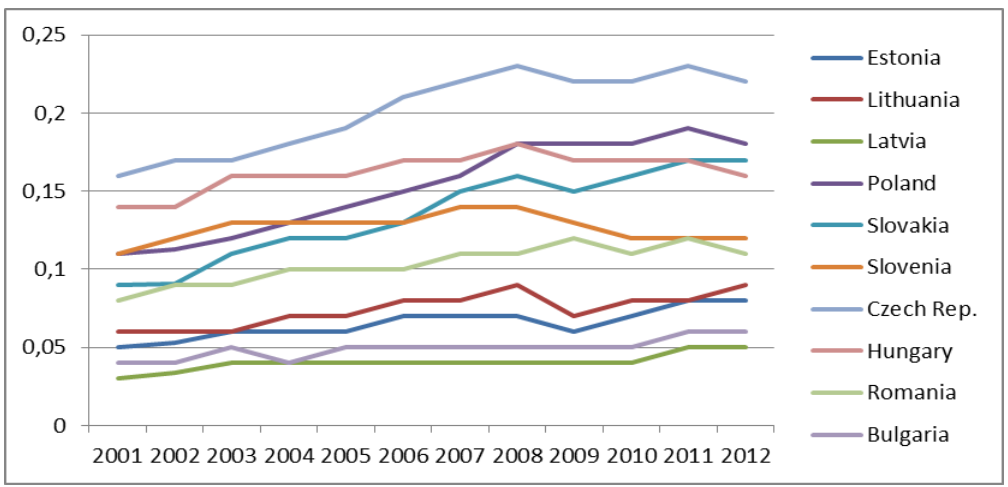

Figure 3. Competitive Industrial Performance Index score of selected countries, 2001-2012

Source: Own processing with the UNIDO data, available online at: http://www.unido.org/data1/Statistics/Research/cip.html (Accessed on 05.08.2016) 
According to CIP index, the industrial leader among the analysed countries is Czech Republic with CIP value - 0, 22, followed by Poland $(0,18)$, Slovakia $(0,17)$ and Hungary $(0,16)$. These EU transition economies are included in the top quintile of CIP 2016, as being among the world's most industrialized countries, mostly due to their export orientation, more focused on the European market. In the upper middle quintile of CIP are Slovenia $(0,12)$, Romania $(0,11)$, Lithuania $(0$, 09), Estonia $(0,08)$, Bulgaria $(0,06)$, while Latvia $(0,05)$ is included in the middle quintile of CIP (UNIDO, 2015). A strong interconnection between the evolutions of $\mathrm{CIP}$ Index and the EU expenditure in the region for almost all East EU states can be noticed. This fact is demonstrated by impressively high correlation index registered by Slovakia and Poland - 0, 94 and respectively of 0, 93; Romania 0, 86; Czech Republic 0, 85 and Latvia 0, 8. Strong correlations are, also, registered for Bulgaria 0,76; Lithuania 0,74 and Estonia 0,71. Moderate correlation index could be assessed for Hungary, 0, 59. For all these countries, except Slovenia correlation index of which is $-0,04$, the increase of EU funding had a favourable impact upon the industrial development. These findings are in tandem with the growth rates of high tech exports, where Latvia $(+299 \%)$, Poland $(+174 \%)$, Slovakia $(+165 \%)$, Bulgaria $(+138 \%)$ and Lithuania $(+103 \%)$ registered, in the period of 20012014, growth rates for high tech goods higher than $100 \%$ (Own calculations based on World Bank data, 2016). Despite the fact that the growth rate of high tech exports of Czech Republic is lower than comparing to the other analysed countries, the correlation is still the stronger, due to the higher industrialization level of Czech Republic in comparison with the other analysed countries. Moderate correlations for Hungary and Estonia and Slovenia are explained by the weak performances of these countries in increasing the high-tech exports, registering relative low growth rates (Slovenia: $+9 \%$ ) or even negative growth rates (Hungary: $-43 \%$ and Estonia: $-41 \%$ ) (World Bank, 2016b).

At this point, it can be concluded mentioned that investment in research and innovation from the EU budget has greatly improved scientific excellence in Europe and strengthened its competitiveness by improving industry's capacity to innovate in the period between 2007 and 2013 (EC, 2016). These statements are proved by the calculated correlation relations. Both relations between EU funds and GII and CIP Index reveal positive correlations, except for Slovakia (in case of EU financing and GII correlation) and Slovenia (in case of EU financing - CIP Index relation), which once again highlight the important role of European integration and European funds in fostering the economic competitiveness of NMS. The differences in the correlation relations, explain the variety of factors determining the competitiveness. The use of the composite index for performance analysis has not been free from controversy. Many statisticians argue that a composite index, while attempting to capture many things at the same time, essentially does not provide a precise measure of anything, and thus sends a simplistic and misleading message to policymakers about the complexity of the issue at hand. Despite this drawback, policymakers and development practitioners value a composite measure which summarizes complex processes in a single measure that can be used to benchmark their country's performance. Nevertheless, in our case, the correlations obtained suggest that EU funds contributed to the increase in the competitiveness of the analyzed countries, but were not the only drivers of it.

\subsection{Correlation between EU Competitiveness and Economic Freedom of NMS}

Each country, to greater or lesser extent, is aware of its basic needs. Basic prerequisites for national economic development, inter alia, - capital, especially in the form of Foreign Direct Investment (FDI) which contributes more to growth than domestic investment (Borensztein, De Gregorio and Lee, 1998) and investment in infrastructure, knowledge creation and human capital - are crucial for innovative performance. Furthermore, though a country might have to rely on, or deal with exogenous factors such as the advantages of FDI, international aid and/or collaboration, in order to improve its performance, it has to start its own innovative work either in parallel or at some stage (Oukil, 2009) in order to solve local problems.

As a vital element of human dignity, autonomy, and personal empowerment, economic freedom is valuable as an end itself. Just as important, however, is the fact that economic freedom is the key to achieving the broad-based economic dynamism that ensures lasting inclusive growth and increased prosperity for society as a whole. As Friedrich Hayek (1944) foresaw decades ago, "the guiding principle in any attempt to create a world of free men must be this: a policy of freedom for the individual is the only truly progressive policy." (Hayek, 1944)

Analysing data from Global Competitiveness Report and Economic Freedom of the World, it is revealed the existence of a positive connection, the level of economic freedom significantly influencing the competitiveness of selected countries (Table 2). Comparison of the ranks registered, in different years, by countries in the $\mathrm{GCl}$ and IEF rankings does not lead to any relevant finding, due to the fact that during the years the number of countries taken into analysis and the methodology was changed. Nevertheless, the regression analysis, performed by Bujanca and UIman (2015), shows that countries rated as 
highly economically free are also perceived as being high competitive (Bujanca and Ulman, 2015). That is why, another important dimension which should be analysed is the effect of EU funding upon NMS' economic freedom score.

Table 2. Evolution of EU NMS in the Global Competitiveness Index (GCI) Ranking and Economic Freedom (IEF) Ranking, 2007, 2016 (position)

\begin{tabular}{|c|c|c|c|c|c|c|c|c|c|c|c|}
\hline \multicolumn{2}{|c|}{ Countries } & \multicolumn{3}{|c|}{ Baltic Countries } & \multicolumn{5}{|c|}{ Central European Countries } & \multicolumn{2}{|c|}{ S-E EU Countries } \\
\hline Index & Years & $\begin{array}{l}\text { Eston } \\
\text { ia }\end{array}$ & $\begin{array}{l}\text { Lithu } \\
\text { a-nia }\end{array}$ & $\begin{array}{l}\text { Lat } \\
\text { via }\end{array}$ & $\begin{array}{l}\text { Polan } \\
\text { d }\end{array}$ & $\begin{array}{l}\text { Slovaki } \\
\text { a }\end{array}$ & $\begin{array}{l}\text { Sloveni } \\
\text { a }\end{array}$ & $\begin{array}{l}\text { Czec } \\
\text { h } \\
\text { Rep. }\end{array}$ & $\begin{array}{l}\text { Hungar } \\
\text { y }\end{array}$ & $\begin{array}{l}\text { Romani } \\
\text { a }\end{array}$ & $\begin{array}{l}\text { Bulgari } \\
\text { a }\end{array}$ \\
\hline \multirow[t]{2}{*}{ GCl } & $\begin{array}{l}\mathbf{2 0 0 7} \\
\text { (out of } \\
125 \text { ) }\end{array}$ & 25 & 40 & 36 & 48 & 37 & 33 & 29 & 41 & 68 & 72 \\
\hline & $\begin{array}{l}2016 \\
\text { (out of } \\
140 \text { ) }\end{array}$ & 30 & 36 & 44 & 41 & 67 & 59 & 31 & 63 & 53 & 54 \\
\hline \multirow[t]{2}{*}{ IEF } & $\begin{array}{l}2007 \\
\text { (out of } \\
157 \text { ) }\end{array}$ & 12 & 22 & 41 & 87 & 40 & 58 & 31 & 44 & 67 & 62 \\
\hline & $\begin{array}{l}2016 \\
\text { (out of } \\
178 \text { ) }\end{array}$ & 9 & 13 & 36 & 39 & 56 & 90 & 21 & 58 & 61 & 60 \\
\hline
\end{tabular}

Source: Own processing with the WEF $(2015,2006)$ and Heritage Foundation data $(2016,2007)$

The Index of Economic Freedom, calculated since 1996 by The Heritage Foundation and The Wall Street Journal, takes a comprehensive view of economic freedom. Some of the aspects of economic freedom that are evaluated are concerned with a country's interactions with the rest of the world-for example, the extent of an economy's openness to global investment or trade. Most, however, focus on policies within a country, assessing the liberty of individuals to use their labour or finances without undue restraint and government interference (Miller, T, Kim A.B, 2016). The greater is the score registered by a country, more liberal is considered the economy. If the country is characterized by higher economic freedom, more competitive it will be considered (Miller, T, Kim A.B, 2016). As a result, the present study shows that countries with institutions and policies more consistent with economic freedom, have more rapid economic growth, higher investment rates, higher income levels and more rapid reductions in poverty rates. Figure 4 shows the evolution of the IEF for NMS in the period of 2006-2016 (Figure 4).

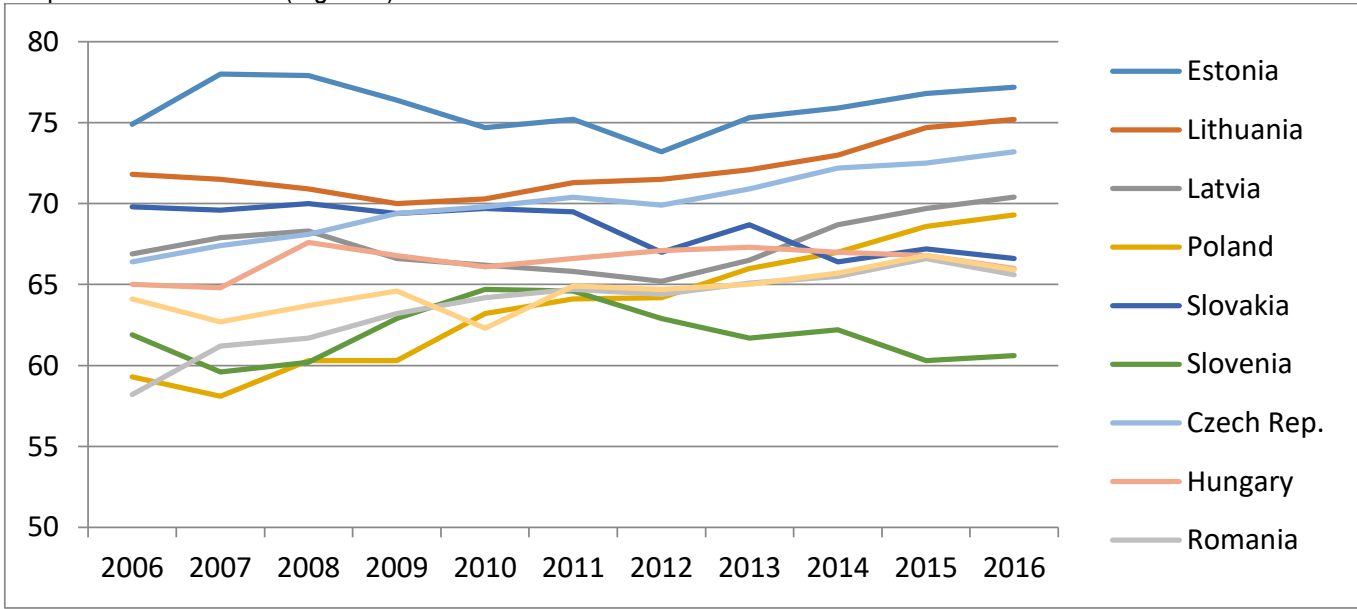

Figure 4. Index of Economic Freedom score by NMS (max 100 points)

Source: Own processing with the Heritage Foundation data, available at: http://www.heritage.org/indexl. (Accessed on 02.08.2016) 
According to Figure 4, most of the NM countries have increased their score in the IEF ranking since 2006. One of the factors relies on the hypothesis that the EU financing, which was allocated to the institutional strengthening and fostering of the business environment, positively influenced the economic liberty and respectively, higher external competitiveness for NMS. The highest correlation between the allocation of EU financing and the evolution of Economic Freedom Index is registered for Poland $(0,95)$, Czech Republic $(0,88)$ and Romania $(0,8)$, while the lowest correlation indicator for Slovakia $(-0,55)$ and Estonia $(-0,6)$ (see Table 3).

\section{Conclusions}

In conclusion it can be stated that the European Integration of Baltic, Central and South Eastern European countries provided new opportunities for economic development. The business environment and economic infrastructure improvement has led to the increased international competitiveness of the countries. One of the most important instruments of European integration is the redistribution of financial resources or EU funding, which is intended to assure economic and social cohesion between the Western EU countries and Eastern ones. The NMS have benefited extensively from EU funding, especially after their integration into the EU, oriented towards different areas of economic activity and capacity building. Therefore, European integration of NMS, and therefore EU funding, resulted in impressive outcomes such as infrastructure development, empowered economic potential, business activity acceleration and the improvement of the countries' economic attractiveness on the international markets.

EU financing had a beneficial impact upon the improvement of innovative capacities. The correlation between EU funds and Innovation performance of the analysed countries highlights that EU expenditure in the region has greatly improved scientific excellence in Europe and strengthened its competitiveness by improving industry's capacity to innovate. These statements are proved by the calculated correlation relations (Table 3).

Table 3. Correlation indexes between EU financing and selected indicators

\begin{tabular}{|l|l|l|l|l|}
\hline Correlation Index & $\begin{array}{l}\text { EU fin. \& CA to } \\
\text { GDP }\end{array}$ & EU fin. \& GII & EU fin. \& CIP & $\begin{array}{l}\text { EU fin. \& Econ. Free. } \\
\text { Index }\end{array}$ \\
\hline Baltic Countries & 0,5 & 0,58 & 0,71 & $-0,6$ \\
\hline Estonia & 0,13 & 0,85 & 0,74 & 0,08 \\
\hline Lithuania & 0,21 & 0,96 & 0,81 & $-0,33$ \\
\hline Latvia & \multicolumn{5}{l}{} \\
\hline Central European Countries & 0,85 & 0,93 & 0,95 \\
\hline Poland & $-0,07$ & $-0,82$ & 0,94 & $-0,55$ \\
\hline Slovakia & 0,21 & 0,82 & $-0,04$ & 0,53 \\
\hline Slovenia & 0,44 & 0,75 & 0,85 & 0,88 \\
\hline Czech Republic & 0,66 & 0,65 & 0,59 & 0,49 \\
\hline Hungary & 0,81 & \multicolumn{2}{l}{} \\
\hline South Eastern EU Countries & 0,42 & 0,86 & 0,8 \\
\hline Romania & 0,03 & 0,76 & 0,76 & 0,6 \\
\hline Bulgaria & 0,26 & \multicolumn{2}{l|}{} \\
\hline
\end{tabular}

Source: Own calculations

Since their accession to the EU, all the analysed countries have impressively increased their level of competitiveness. The role of EU financing in enhancing external competitiveness is more visible for some countries and less for the others. Both relations between EU funds and GII and CIP Index reveal positive correlations, except for Slovakia (in case of Business Innovation index) and Slovenia (in case of CIP Index), which once again highlight the important role of European integration and European funds in fostering the economic competitiveness of NMS. The differences in the correlation relations, explain the variety of factors determining the competitiveness in the nalysed countries. Nevrtheless, the regression analysis shows that countries rated as highly economically free are also perceived as being high competitive. The highest correlation between the allocation of EU financing and the evolution of Economic Freedom Index is registered for Poland - 0, 95; Czech Republic - 0, 88 and Romania - 0, 8, while the lowest correlation indicator for Slovakia - 0, 55 . 
Despite the differences in the correlations calculated between EU financing received by the NMS and different analysed indicators, the obtained results suggest that EU funds contributed to the increase in the competitiveness of the analyzed countries, but were not the only drivers of it. Therefore, the European integration and the EU financing instruments had important effects in improving the living conditions of EU citizens and in assuring competitive economic environment for business activities and research in the NMS.

\section{References:}

[1] Balázs P. et all (2014). 25 Years after the fall of The Iron Curtain. The State Of Integration Of East And West In The European Union. European Commission, 2014. ISBN 978-92-79-38535-3. [Online] Available: https://ec.europa.eu/research/social-sciences/pdf/policy_reviews/east-west_integration.pdf

[2] Balcerowicz L. et all (2013). Economic Growth in the European Union, Lisbon Council e-book. ISBN 978-90902-7915-2. [Online] Available:

http://www.lisboncouncil.net/growth/documents/LISBON_COUNCIL_Economic_Growth_in_the_EU\%20(1).pdf

[3] Becker S. (2012). EU Structural Funds: Do They Generate More Growth? The CAGE- Chatham House Series, No. 3, December 2012. [Online] Available:

https://www.chathamhouse.org/sites/files/chathamhouse/public/Research/International\%20Economics/1212bp becker.pdf

[4] Borensztein, E., De Gregorio, J. and Lee, J.W. (1998) How does foreign direct investment affect economic growth? Journal of International Economics, vol. 45, 115-135.

[5] Bujanca G. V., Ulman S.R. The Impact of the Economic Freedom on National Competitiveness in the Main Economic Power Centres in the World. Procedia Economics and Finance, Vol. 20 (2015), 94 - 103.

[6] Ciocanela A.B. , Pavelescu A.B. (2015). Innovation and competitiveness in European context. Procedia Economics and Finance, 32, $728-737$.

[7] European Commission (2016). EU financing by country 2000-2014. [Online] Available: http:// ec.europa.eu/EU expenditure and revenue 2000-2014 data download

[8] EC (2016). EU research funding boosts scientific excellence and competitiveness, European Commission press release. Brussels, 25 January 2016. [Online] Available: http://europa.eu /rapid/press-release_IP-16145_en.htm

[9] EC (2014). European Structural and Investment Funds. [Online] Available:

http://ec.europa.eu/regional_policy/en/funding/

[10] Focus Economics (2015). Current Account (\% of GDP). [Online] Available: http://www.focuseconomics.com/economic-indicator/current-account-balance (12.08.2016)

[11] Hagen, T. and Mohl, P. (2009). "How does EU Cohesion Policy work? Evaluating its effects with regard to various outcome variables", Center of European Economic Research and University of Heidelberg

[12] Hayek F.A. The Road to Serfdom (Chicago: University of Chicago Press, 1944).

[13] KPMG (2014). EU funds in Central and Eastern Europe progress report 2007-2014. [Online] Available:https://www.kpmg.com/SI/en/lssuesAndlnsights/ArticlesPublications/Documents/EU-Funds-inCentral-and-Eastern-Europe.pdf

[14] Manyika, J. Et all. (2013). Disruptive Technologies: Advances That Will Transform Life, Business, and the Global Economy. Washington, DC: McKinsey Global Institute

[15] Miller T., Kim A.B. (2016). Index of Economic Freedom. Chapter 2: Defining Economic Freedom. [Online] Available: http://www.heritage.org/index/book/chapter-2 (15.08.2016)

[16] OECD (2016) Current Account to GDP ratio- external competitiveness indicator. [Online] Available: https://data.oecd.org/trade/current-account-balance.htm (14.08.2016) 
[17] Oukil, M-S. (2009). Enhancing innovation for sustainable growth and competitiveness in North African countries. International Journal of Technology Management. Geneva. vol. 45, Issue 1/2.

[18] Păun C. (2014). The Socio-economic Impact of European Funds on Eastern European Countries, Volume 4, Issue 1. [Online] Available: http://www.irsr.eu/issue10/04_Paun_p49-56.pdf

[19] Rechnitzer J., Engyel I. (2013). The Competitiveness Of Regions In The Central European Transition Countries. [Online] Available: http://macrotheme.com/yahoo_site_admin/assets/docs/

9LengyelMR24.13191544.pdf

[20] Roaf J. et all (2014). 25 Years of Transition Post-Communist Europe and the IMF. ISBN: 978-1-49834-201-8. [Online] Available: https://www.imf.org/external/pubs/ft/reo/2014/eur/eng/ pdf/erei_sr_102414.pdf

[21] Sanfey P, Zeh S. (2012). Making sense of competitiveness indicators in south-eastern Europe. European Bank for Reconstruction and Development. [Online] Available: http://www.ebrd .com/downloads/research/economics/workingpapers/wp0145.pdf

[22] Sohinger J. (2004). Transforming Competitiveness in European Transition Economies: The Role of Foreign Direct Investment. [Online] Available: http://ies.berkeley.edu/pubs/ workingpapers/PEIF-17Transforming_Competitiveness.pdf

[23] The Heritage Foundation (2016). Index of Economic Freedom 2006-2016. [Online] Available: http://www.heritage.org/index/explore

[24] UNIDO (2015). Industrial Development Report 2016. The Role of Technology and Innovation in Inclusive and Sustainable Industrial Development. Vienna, 2015. elSBN: 978-92-1-057637-6

[25] WEF (2006). The Global Competitiveness Report 2006-2007. Geneva, ISBN-13: 978-1-4039-9636-7. p 1617. [Online] Available: http://www3.weforum.org/docs/WEF_Global CompetitivenessReport_2006-07.pdf (20.07.2016)

[26] WEF (2015). The Global Competitiveness Report 2015-2016. Geneva, 2015, p.385. ISBN-13: 978-92-9504499-9. [Online] Available: http://www3.weforum.org/docs/gcr/2015 2016/Global_Competitiveness Report_2015-2016.pdf (20.07.2016)

[27] WIPO, INSEAD and Johnson Uornell university (2016), The Global Innovation Index Reports 2007 -2015. [Online] Available: https://www.globalinnovationindex.org /content/page/past-reports/

[28] World Bank (2016a). Current Account to GDP ratio. [Online] Available: http://data.worldbank.org/indicator/BN.CAB.XOKA.GD.ZS

[29] World Bank (2016b), High-technology exports (\% of manufactured exports). [Online] Available: http://data.worldbank.org/indicator/TX.VAL.TECH.MF.ZS?view=chart 